\title{
Effect of Disproportional Voting Rights on Firm's Market Performance: Evidence from Chinese Firms Cross-Listed on U.S. Exchanges
}

\author{
Abdullah *, Jia'nan Zhou and Muhammad Hashim Shah \\ School of Economics and Management, Southwest Jiaotong University, Chengdu 610031, China; \\ zjncf76@aliyun.com (J.Z.); shah_shah7113@yahoo.com (M.H.S.) \\ * Correspondence: abdiman.0688@yahoo.com; Tel.: +86-158-8248-3341 \\ Academic Editor: Nicholas Apergis \\ Received: 23 May 2017; Accepted: 30 August 2017; Published: 8 September 2017
}

\begin{abstract}
Dual-class firms face great criticism as it is believed that firms choose this structure to expropriate minority shareholders' wealth. We compare market performance of Chinese dual-class firms with their single-class counterparts by constructing a list of Chinese firms cross-listed on U.S. exchanges. We find, contrary to the literature, that Chinese dual-class firms are outperforming in terms of market performance measured by Tobin's Q, P/E ratio, and abnormal return in both subsequent years after the initial public offering (IPO). The reason for contrary results is that Chinese dual-class firms bond themselves to high U.S. standards from low local Chinese standards, and it is evident from the literature that when a firm bonds itself to high standards it shows a credible commitment towards minority shareholders' rights, as well as focus on upright performance rather than investing in value-destroying projects and competes to survive in the market that imposes the high standards.
\end{abstract}

Keywords: dual-class firms; disproportional voting rights; market performance; Chinese cross-listed firms; initial public offering

JEL Classification: G30

\section{Introduction}

The dual-class structure is a controversial way of accessing capital markets as it deviates from the "one share-one vote" regime that is commonly used by firms. Such firms face great criticism by academicians, investors, and practitioners. They usually go public with two classes of shares, one carrying superior voting rights and the other carrying restricted voting rights, whereas cash flow rights for both classes of shares are identical. Shareholders of superior voting shares usually participate in the management of the company and make the majority of decisions as the controlling block is held by them. The inequality of voting rights creates agency conflict, which assumes to affect performance of a company. This paper extends the research on dual-class-structured firms, especially in the dimension of market performance. We study a sample of Chinese firms cross-listed on U.S. exchanges and we use this dataset to compare the market performance of single-class vs dual-class firms. Studying Chinese firms is especially important as China has grown at an exponential rate over the last two decades. Jiang and Kim (2015) encourage future researchers to study cross-listed firms as very few studies have been carried out focusing on Chinese cross-listed firms. We study a sample of 121 Chinese firms cross-listed on U.S. exchanges consisting of 33 dual-class and 88 single-class firms. The study of this sample is tremendously important as Chinese local exchanges do not allow firms to list locally with multiple classes of shares and they choose U.S. exchanges for listing. 
Chinese cross-listed firms are ignored by researchers mainly due to the lower number of firms. Jiang and Kim (2015) encourage future researchers to study cross-listed firms in China, and express hope that when the number of Chinese cross-listed firms increases, more studies will be carried out to study them. China has been growing exponentially, especially over the last two decades; therefore, understanding Chinese cross-listed firms is particularly important. The Shanghai and Shenzhen stock exchanges are still young and volatile. China still has an approval-based system, whereas many developed countries have moved to a registration-based system; therefore, it is quite difficult to raise equity in China. Abdullah et al. (2017a) show that the presence of dual-class structures in Chinese firms cross listed to the U.S. is higher than any other country's cross-listed firms, mainly because China does not allow firms to list with multiple classes of shares; therefore, studying this sample is tremendously important.

Our findings are contrary to most of the literature available on this topic and contribute to the literature in several ways. The literature suggests that divergence between cash flow rights and voting rights lower a firm's value. It is believed that insiders of dual-class firms expropriate minority shareholders' wealth by investing in value-destroying projects and investors attach low value to dual-class firms as dual-class firms usually possess high degrees of entrenchment. We find, contrary to literature, that dual-class firms of China outperform single-class firms in terms of Tobin's $Q$, abnormal returns, and $\mathrm{P} / \mathrm{E}$ ratio. Through descriptive analysis, we observe that dual-class firms underperform before initial public offering (IPO), improve in the first year, and outperform in the second year after IPO compared to single-class counterparts in terms of operating performance measured by ROA (return on assets) and EPS (earning per share). We observe that $42.42 \%$ of dual-class firms belong to the IT industry, which runs on innovation and innovation tends not to produce results in the short-term. This may be the reason for dual-class outperformance in the second year after IPO. We observe, contrary to the literature, that Chinese dual-class firms are outperforming single-class firms in terms of market performance as measured by $\mathrm{P} / \mathrm{E}$ ratio, Tobin's $\mathrm{Q}$, and abnormal stock returns in both years after IPO, whereas the literature suggests that investors attach low value to dual-class firms as investors perceive that insiders entrench management to expropriate minority shareholders' wealth (Claessens et al. 2000; Lins 2003; Yeh and Woidtke 2005; Baulkaran 2014).

We use OLS (ordinary least squares) regression to compare the market performance of single-class vs dual-class firms of our sample. Interestingly, we find that Chinese dual-class firms are outperforming single-class counterparts in market performance in both years after IPO. We find a positively-significant relationship market performance variables $\mathrm{P} / \mathrm{E}$ ratio, Tobin's $\mathrm{Q}$, and abnormal return with the structure choice of the firm. The possible reason for contrary results is that Chinese dual-class firms bond themselves to the high standards of U.S. exchanges as opposed to the low Chinese local standards, which shows their credible commitment towards shareholders' rights. When a firm bonds itself with U.S. exchanges, it decreases insiders' abilities to extract private benefits and it gives a positive sign for their credible commitment towards shareholders' rights (Doidge 2004). Jiang and Kim (2015) witness that shareholder's rights are less protected and corporate governance is weak in China. Chinese dual-class firms bond themselves to high standards which give sign of their credible commitment and show that insiders intend to positively enhance firm value in order to compete and survive in the market imposing high standards.

This paper is organized in five sections. The first section introduces the paper, the following section gives insight with a literature review. Section 3 explains the data, descriptive statistics, and methodology, followed by a discussion of the results. The last section concludes the paper with recommendations for future researchers.

\section{Literature Review}

Empirical research on the effect of deviation from a "one share-one vote" regime on performance has a long history and it is widely discussed in the literature. Different authors investigate this effect and conclude with different opinions, but mainly they can be divided into two groups or schools of 
thought (Jog et al. 2010). Researchers from the first school of thought argue that insiders of dual-class firms entrench management with superior voting rights which result in the expropriation of minority shareholders' rights and this entrenchment leads to negative performance (Grossman and Hart 1988). Agency conflict may rise due to controversial voting structure. Restricting the voting rights of restricted voting shareholders will lead to weaker governance structures, which would ultimately affect the performance of the firm. Researchers from the second school of thought argue that the dual-class structure allows insiders to manage firms and create value for the long-term, which also encourages families and entrepreneurs to invest more in specific human capital as they continue to control the firm (Bergström and Rydqvist 1990; Amoako-Adu and Smith 2001; Cronqvist and Nilsson 2003; Share 2004). In general, investors are most likely to react to stock performance in accordance with the portfolio theory. They usually adjust their portfolio by watching the performance of the stock compared to the performance of other stocks available in the stock market. Investors are likely to shift from the poorly-performing stocks to better-performing stocks.

As explained earlier, there is a difference of opinion existing between the researchers regarding the performance of single-class firms vs dual-class firms. Baulkaran (2014) states that investors attach low value to dual-class firms as dual-class firms possess high degrees of entrenchment, which gives benefits to insiders and imposes an agency cost to outside shareholders. Core et al. (1999) find firms with great agency problems perform worse. Adams and Santos (2006) find a positive relationship between managerial control for small stakes and performance, but when the control becomes too large, negative consequences on performance occur. Claessens et al. (2000), Lins (2003), Yeh and Woidtke (2005), and Gompers et al. (2010) conclude that divergence between voting rights and cash flow rights lead to lower firm value, and even the performance of the firm becomes poorer. Smart et al. (2008) find that dual-class firms neither show better, nor worse, performance than their single-class counterparts. Bohmer et al. (1996) find that firms going public with multiple classes of shares outperform both in terms of operating performance, as well as stock performance.

We compare the stock market performance of single-class vs dual-class firms included in our sample. We use Tobin's $Q$, abnormal return, and $\mathrm{P} / \mathrm{E}$ ratio to investigate whether dual-class firms of China are outperforming their single-class counterparts. These variables are frequently used to measure the stock market performance of firms in past literature (e.g., Gompers et al. 2003; Smart and Zutter 2003; Adams and Santos 2006; Smart et al. 2008; Jog et al. 2010). The results are discussed in detail in the discussion of results section of the paper.

\section{Data, Descriptive Analysis, and Methodology}

In order to compare the stock performance of single-class firms vs dual-class firms, we study a sample of 121 Chinese firms cross-listed with U.S. exchanges. The sample consists of 33 dual-class firms and 88 single-class firms. The sample used for this study looks very small, but it is adequate as these are only Chinese firms cross-listed in U.S. exchanges. It is evident from the literature that few Chinese firms have been cross-listed to U.S. exchanges to date. We cannot include cross-listed firms from Hong Kong in our sample to increase its size, as there are several differences (like cultural and geographical aspects, and listing regulations) that would void sample matching, which is very important in order to evaluate performance difference. The Hong Kong and Singapore exchanges do not allow firms to list with multiple classes of shares; therefore, we cannot include Chinese firms cross listed there in order to compare performance between single- and dual-class firms. Recently, Hong Kong exchanges disallowed Ali Baba (Alibaba Group Holding Limited, Hangzhou, China) listing with multiple classes of shares. We only use Chinese firms cross listed on U.S. exchanges that best match in all aspects. We believe that this sample is suitable for investigating the performance differences between Chinese single- and. dual-class firms. We believe, for most of four sample firms, that cross listing and initial public offering occurs at the same time. We use F-1, S-1, 20-F, and 10-K (available on www.sec.gov) filings to collect financial data for our sample firms. We use the official NASDAQ website to collect the stock market prices but, as the official NASDAQ website limits the market data 
for the last 10 years, we use Google finance (Google, Inc., Montain View, CA, USA; www.google.com/ finance) and Yahoo finance (Yahoo! Inc., Sunnyvale, CA, USA; https:/ / finance.yahoo.com/) to collect the data for the companies listed prior to those 10 years. We delete the outliers, where they introduce noise to the results. We only take two years of data because 10 dual-class firms of our sample were cross-listed in 2014; thus, we have to limit our study to only two years.

Abdullah et al. (2017a) use the same sample, and find that Chinese dual-class firms are larger in size, possess more institutional ownership, possesses noticeable ownership concentration, and are relatively older than single-class firms. They also find that restricted voting shareholders hold $20 \%$ of voting rights, whereas $80 \%$ of voting rights are held by shareholders with superior voting rights. They also find that $42.42 \%$ of Chinese dual-class firms belong to the IT industry, and Chinese dual-class firms prefer to cross list on the NYSE, whereas Chinese single-class firms prefer to cross list on NASDAQ, which is in line with the literature. They fail to find that firms with excessive family ownership choose to list with multiple classes of shares in order to retain control in their own hands. As explained earlier, firms with noticeable ownership concentration desire listing with multiple classes of shares in order to retain control in their own hands. They also argue that when firms foresee growth opportunities and do not have enough capital to invest, and insiders additionally do not want to lose control, listing with multiple classes of shares is good option for them.

Table 1 presents the descriptive statistics of our sample data; we use this table to illustrate whether there is a noteworthy difference existing between dual- and single-class firms in our sample. This table shows that dual-class firms underperform single-class firms in terms of operating performance measured by ROA and EPS prior to IPO, show improvements in the first year after IPO, and outperform in the second year after IPO. We observe that $42.42 \%$ of Chinese dual-class firms belong to the IT industry, which runs on innovation and produces results in the short-term. This may be the reason why dual-class firms outperform in the second year after IPO. We also witness that dual-class firms outperform single-class firms in terms of market performance measured by $\mathrm{P} / \mathrm{E}$ ratio, Tobin's $\mathrm{Q}$, and abnormal stock return. This finding is contrary to the literature, the reasons of which are presented later in this paper.

Table 1. Descriptive statistics of the dataset representing Chinese dual- and single-class firms cross-listed in the U.S.

\begin{tabular}{|c|c|c|c|c|c|}
\hline Firm Characteristics & Dual-Class & Single-Class & Difference & $t$ Value & Sig. \\
\hline \multirow{2}{*}{ ROA prior to IPO } & 0.105 & 0.133 & -0.028 & \multirow{2}{*}{-2.469} & \multirow{2}{*}{$0.016^{* * *}$} \\
\hline & 0.059 & 0.114 & -0.087 & & \\
\hline \multirow{2}{*}{ ROA 1st year after IPO } & 0.054 & 0.380 & -0.326 & \multirow{2}{*}{-1.058} & \multirow{2}{*}{0.293} \\
\hline & 0.053 & 0.089 & -0.036 & & \\
\hline \multirow{2}{*}{ ROA 2nd year after IPO } & 0.040 & 0.019 & 0.021 & \multirow{2}{*}{-0.518} & \multirow{2}{*}{0.607} \\
\hline & 0.055 & 0.064 & -0.05 & & \\
\hline \multirow{2}{*}{ EPS prior to IPO } & -0.823 & 0.115 & -0.938 & \multirow{2}{*}{2.117} & \multirow{2}{*}{$0.040^{* *}$} \\
\hline & -0.030 & 0.161 & -0.191 & & \\
\hline \multirow{2}{*}{ EPS 1st year after IPO } & -0.022 & 0.319 & -0.341 & \multirow{2}{*}{-1.740} & \multirow{2}{*}{$0.085 *$} \\
\hline & 0.050 & 0.172 & -0.122 & & \\
\hline \multirow{2}{*}{ EPS 2nd year after IPO } & 0.251 & 0.235 & 0.020 & \multirow{2}{*}{0.152} & \multirow{2}{*}{0.880} \\
\hline & 0.070 & 0.220 & -0.150 & & \\
\hline \multirow{2}{*}{ Abnormal return 1st year after IPO } & $-5 \%$ & $-17 \%$ & $12 \%$ & \multirow{2}{*}{0.814} & \multirow{2}{*}{0.418} \\
\hline & $-14 \%$ & $-34 \%$ & $20 \%$ & & \\
\hline \multirow{2}{*}{ Abnormal return 2 nd year after IPO } & $-9 \%$ & $-25 \%$ & $16 \%$ & \multirow{2}{*}{2.048} & \multirow{2}{*}{$0.044^{* *}$} \\
\hline & $-13 \%$ & $-38 \%$ & $26 \%$ & & \\
\hline \multirow{2}{*}{$\mathrm{P} / \mathrm{E}$ ratio 1st year after IPO } & 64.48 & 61.41 & 3.07 & \multirow[b]{2}{*}{-0.167} & \multirow{2}{*}{0.868} \\
\hline & 24.98 & 11.93 & 13.04 & & \\
\hline \multirow{2}{*}{$\mathrm{P} / \mathrm{E}$ ratio 2 nd year after IPO } & 110.69 & 64.88 & 45.81 & \multirow{2}{*}{1.473} & \multirow{2}{*}{0.147} \\
\hline & 27.94 & 11.75 & 16.19 & & \\
\hline
\end{tabular}


Table 1. Cont.

\begin{tabular}{|c|c|c|c|c|c|}
\hline Firm Characteristics & Dual-Class & Single-Class & Difference & $t$ Value & Sig. \\
\hline \multirow{2}{*}{ Tobin's Q 1st year after IPO } & 14.24 & 8.56 & 5.68 & \multirow[b]{2}{*}{1.550} & \multirow[b]{2}{*}{0.127} \\
\hline & 8.99 & 2.82 & 6.16 & & \\
\hline \multirow{2}{*}{ Tobin's Q 2nd year after IPO } & 8.53 & 4.49 & 4.04 & \multirow{2}{*}{2.117} & \multirow[b]{2}{*}{$0.040^{* *}$} \\
\hline & 4.92 & 1.79 & 3.13 & & \\
\hline
\end{tabular}

This table shows descriptive statistics of the sample data drawn from 121 Chinese firms cross-listed in the U.S., which includes 33 dual-class and 88 single-class firms. The top and bottom figures for each characteristic are the mean and median, respectively. ${ }^{*}, * *$, and ${ }^{* * *}$ indicate statistical significance at the 10,5 , and $1 \%$ levels, respectively. IPO: initial public offering; ROA: return on assets; Sig.: significance EPS: earning per share.

We use OLS regression for the comparison of market performance between dual and single-class firms. The dependent variables are abnormal market return, Tobin's $Q$, and $P / E$ ratio. The independent variable is the structure of the firm, which has two values $(1=$ firms with dual-class structure and $0=$ if the firm is single-class). We use ROA, institutional investment and CEO-Chairman duality to control the effect of operating performance on stock market performance of the firm. We also use institutional investment and CEO-Chairman Duality to control the effect of corporate governance practices of firm on their market performance. Our regression model is mentioned below:

$$
\text { Market performance }=\propto_{0}+\propto_{1} \text { Structure }+\propto_{2} \text { Control variable }+ \text { ed. }
$$

\section{Discussion of Results}

Tables 2-4 present the regression results for Tobin's $Q$, abnormal return, and $\mathrm{P} / \mathrm{E}$ ratio respectively. Tobin's $Q$ is the measure of market value compared to its replacement cost which is calculated as the total market value of firm divided by the total book value of assets. Abnormal rate of return is defined as the difference between the expected rate of return and actual rate of return in a specific period of time. We calculate the abnormal rate of return for our sample companies by taking the difference of the actual return of stock and market return which is assumed as the expected rate of return. P/E ratio is calculated by stock price per share divided by earnings per share of the firm, which is used to compare among firms which firm is paying more against investment. Structure is a dummy variable, and has a value of 1 if the firm is dual-class, or 0 if otherwise.

We find Chinese dual-class firms are outperforming in terms of market performance compared to single-class firms, which is contrary to most of the literature available on this dimension. We find a significantly positive relationship between Tobin's $Q$, abnormal return, and P/E ratio with the structure choice of the firm. This means that firms listing with multiple classes of shares are outperforming single-class firms in both years after IPO. Claessens et al. (2002), Lins (2003), Gompers et al. (2010), and Baulkaran (2014) argue that insiders of dual-class firms who usually own superior voting shares entrench management to extract private benefits which hurt minority shareholder's wealth; therefore, investors attach low value to dual-class firms. We find, contrary to these studies, that Chinese dual-class firms are showing good performance in the market compared to single-class counterparts. We also find ROA is positively related with market performance variables used in this paper. This means that market performance is also dependent on firm's operating performance, we also witness, through descriptive analysis, that Chinese dual-class firms are outperforming single-class firms in the second year after IPO in terms of ROA and EPS.

We also find that institutional ownership is consistently negatively related to market performance variables in both years after IPO, and for each variable, we choose to measure market performance. This finding is quite interesting, as it is evident from the literature that institutions push firms to adapt adequate governance practices, which affects performance positively (Yermack 1996; Fosberg and Nelson 1999; Kajola 2008). Our findings are contrary to the literature, and may be because of the role of institutions in China. It is believed that institutions either do not have power or desire to engage in the monitoring of firms in China (Tenev et al. 2002; Chen et al. 2007; Jiang and Kim 2015). Abdullah et al. (2017a, 2017b) show that Chinese dual-class firms possess more institutional ownership, 
whereas it is evident from the literature that institutions choose to invest in firms where governance practices are adequate, and resist investing in dual-class firms, as they violate the one share, one vote regime (Giannetti and Simonov 2006; Li et al. 2008; Dey et al. 2016). It is clear from the above discussion that the role of institutional investment is different in China from in other developed countries, as they allow firms to list with dual-class structures, whereas insiders of Chinese dual-class firms may use it to satisfy concerns and to increase investor confidence. We do not witness any significant relationship between CEO-Chairman Duality and market performance variables, whereas other researchers find that CEO-Chairman Duality affects performance negatively (Yermack 1996; Fosberg and Nelson 1999; Kajola 2008; Tian 2013).

Overall, we find support for group of researchers belonging to the second school of thought who argue that the dual-class structure allows insiders to keep control of the firm and invest in long-term value projects which are either costly or difficult to communicate to outside shareholders. We do not observe investors attaching low value to Chinese dual-class firms.

We propose several possible reasons for our contrary results. The first possible reason for outperformance of Chinese dual-class firms is that insiders of these firms enhanced the confidence of investors by cross listing to U.S. which shows their credible commitment towards shareholder's rights as well as firm value as witnessed by previous researchers that firm get more benefit of cross listing when it cross listed from a country where governance standards are low and shareholder's rights are less protected (Coffee 1998, 2002; Stulz 1999; Doidge 2004; Hail and Leuz 2009). Both types of firms cross listed on U.S. exchanges leaving low Chinese standards but even then Chinese dual class firms are performing better. Chinese dual-class firms got edge in benefitting the bonding from low to high standards as it is believed that insiders adopt this structure so that they can expropriate minority shareholder's wealth, but Chinese dual-class firms do not choose to list on Chinese stock exchanges because of which they got edge in enhancing investor's confidence as well as benefiting more from bonding. Investors may get the signal of Chinese dual-class firms insider's credibility since they do not choose to list on Chinese stock exchanges where expropriation of minority shareholder's wealth is comparatively easier therefore; investors does not attach low value rather they attached high value to Chinese dual-class firms compared to Chinese single-class firms cross listed on U.S. exchanges. Besides our study, almost all researchers find that dual-class firms underperform single-class counterparts as they believe that insiders of dual-class firms choose to list with multiple classes of shares in order to extract private benefits and to expropriate minority shareholder's wealth therefore, investors always attach low value to these firms. They all used dual-class firms sample which is listed on the country of origin whereas we study the cross listed sample. Investors also expect these firms to be performing well as these firms intend to perform well, compete, and survive in the market rather than extract private benefits in order to remain on the list. It is very clear that if Chinese dual-class firms have to stay longer on list, they have to compete and perform well. Besides this, they have adapted good governance practices in order to satisfy the concerns of investors whereas this trend is not witnessed by researchers for dual-class firms of other countries which may be another reason of Chinese dual-class firms outperformance. Chinese dual-class firms are hiring more independent directors and possess more institutional ownership compared to single-class counterparts highlighted by (Abdullah et al. 2017b). Investors' confidence increases with the increase in institutional ownership in the firm; when institutions choose to invest in any firm, other individual investors are also likely to invest in the same firm as they believe that institutions have more knowledge and experience. Although, role of institutions in China is doubted but still insiders can use it to enhance confidence of investors. The ratio of independent directors is also positively related with performance of the firm. Therefore, investors' confidence increases when the firm hires more independent directors. We think that these are the possible reasons because of which Chinese dual-class firms are outperforming their single-class counterparts. 
Table 2. Tobin's Q.

\begin{tabular}{|c|c|c|c|c|c|c|c|c|c|c|c|}
\hline \multicolumn{6}{|c|}{ First Year After IPO } & \multicolumn{6}{|c|}{ Second Year After IPO } \\
\hline \multicolumn{6}{|c|}{ Anova } & \multicolumn{6}{|c|}{ Anova } \\
\hline Model & Sum of Squares & Df & Mean Square & F & Sig & Model & Sum of Squares & Df & Mean Square & F & Sig \\
\hline Regression & 1838.371 & 4 & 459.593 & 2.529 & 0.045 & Regression & 713.861 & 4 & 178.465 & 3.475 & 0.010 \\
\hline Residual & $19,809.728$ & 109 & 181.741 & & & Residual & 5597.311 & 109 & 51.351 & & \\
\hline Total & $21,648.099$ & 113 & & & & Total & 6311.172 & 113 & & & \\
\hline \multicolumn{6}{|c|}{ Coefficients } & \multicolumn{6}{|c|}{ Coefficients } \\
\hline & \multicolumn{2}{|c|}{ Unstandardized Coefficients } & \multicolumn{3}{|c|}{ Standard Coefficients } & & \multicolumn{2}{|c|}{ Unstandardized Coefficients } & \multicolumn{3}{|c|}{ Standard Coefficients } \\
\hline Model & B & $\begin{array}{c}\text { Std. } \\
\text { Error }\end{array}$ & Beta & $\mathrm{T}$ & Sig & Model & B & Std. error & Beta & $\mathrm{T}$ & Sig \\
\hline Constant & 13.188 & 3.611 & & 3.653 & 0.000 & Constant & 6.664 & 1.785 & & 3.733 & 0.000 \\
\hline Structure & 6.876 & 2.982 & 0.222 & 2.306 & 0.023 & Structure & 4.536 & 1.532 & 0.271 & 2.960 & 0.004 \\
\hline ROA 1 & 7.953 & 4.786 & 0.155 & 1.662 & 0.099 & ROA 2 & 7.825 & 4.681 & 0.151 & 1.672 & 0.097 \\
\hline $\mathrm{IO} 1$ & -9.310 & 5.558 & -0.165 & -1.675 & 0.097 & $\mathrm{IO} 2$ & -5.576 & 3.028 & -0.175 & -1.842 & 0.068 \\
\hline CEO-Chairman Duality & -1.822 & 3.013 & -0.058 & -0.605 & 0.547 & CEO-Chairman Duality & -1.255 & 1.583 & -0.074 & -0.793 & 0.429 \\
\hline$R^{2}$ & $8.5 \%$ & S.010 & & -0.000 & 0.047 & $R^{2}$ & $11.3 \%$ & 1.000 & & & 0.429 \\
\hline
\end{tabular}

Df: Degrees of freedom; F: F-statistics; B: Beta values; T: T-statistics; IO: Institutional Ownership; Std: Standard.

Table 3. Abnormal Return.

\begin{tabular}{|c|c|c|c|c|c|c|c|c|c|c|c|}
\hline \multicolumn{6}{|c|}{ First Year After IPO } & \multicolumn{6}{|c|}{ Second Year After IPO } \\
\hline \multicolumn{6}{|c|}{ Anova } & \multicolumn{6}{|c|}{ Anova } \\
\hline Model & Sum of Squares & Df & Mean Square & $\mathbf{F}$ & Sig & Model & Sum of Squares & Df & Mean Square & F & Sig \\
\hline Regression & 3.192 & 4 & 0.798 & 2.601 & 0.040 & Regression & 2.532 & 4 & 0.633 & 2.417 & 0.053 \\
\hline Residual & 35.588 & 116 & 0.307 & & & Residual & 30.129 & 115 & 0.262 & & \\
\hline Total & 38.780 & 120 & & & & Total & 32.661 & 119 & & & \\
\hline \multicolumn{6}{|c|}{ Coefficients } & \multicolumn{6}{|c|}{ Coefficients } \\
\hline & \multicolumn{2}{|c|}{ Unstandardized Coefficients } & \multicolumn{3}{|c|}{ Standard Coefficients } & & \multicolumn{2}{|c|}{ Unstandardized Coefficients } & \multicolumn{3}{|c|}{ Standard Coefficients } \\
\hline Model & B & $\begin{array}{c}\text { Std. } \\
\text { error }\end{array}$ & Beta & $\mathrm{T}$ & Sig & Model & B & Std. error & Beta & $\mathrm{T}$ & Sig \\
\hline Constant & -0.044 & 0.148 & & -0.296 & 0.768 & Constant & -0.129 & 0.131 & & -0.984 & 0.327 \\
\hline Structure & 0.204 & 0.119 & 0.161 & 1.715 & 0.089 & Structure & 0.206 & 0.106 & 0.176 & 1.932 & 0.056 \\
\hline ROA 1 & 0.560 & 0.278 & 0.181 & 2.013 & 0.046 & ROA 2 & 0.346 & 0.189 & 0.166 & 1.829 & 0.070 \\
\hline IO 1 & -0.466 & 0.237 & -0.193 & -1.966 & 0.052 & IO 2 & -0.351 & 0.210 & -0.160 & -1.672 & 0.097 \\
\hline CEO-Chairman Duality & 0.020 & 0.120 & 0.016 & 0.167 & 0.868 & CEO-Chairman Duality & 0.006 & 0.112 & 0.005 & 0.052 & 0.958 \\
\hline $\mathrm{R}^{2}$ & $8.2 \%$ & & & & & $\mathrm{R}^{2}$ & $7.8 \%$ & & & & \\
\hline
\end{tabular}


Table 4. P/E ratio.

\begin{tabular}{|c|c|c|c|c|c|c|c|c|c|c|c|}
\hline \multicolumn{12}{|c|}{$\mathrm{P} / \mathrm{E}$ ratio } \\
\hline \multicolumn{6}{|c|}{ First Year After IPO } & \multicolumn{6}{|c|}{ Second Year After IPO } \\
\hline \multicolumn{6}{|c|}{ Anova } & \multicolumn{6}{|c|}{ Anova } \\
\hline Model & Sum of Squares & Df & Mean Square & F & Sig & Model & Sum of Squares & Df & Mean Square & F & Sig \\
\hline Regression & $289,543.224$ & 4 & $72,385.806$ & 2.367 & 0.057 & Regression & $314,970.590$ & 4 & $78,742.648$ & 2.710 & 0.034 \\
\hline Residual & $3,394,382.294$ & 111 & $30,580.021$ & & & Residual & $3,225,642.934$ & 111 & $29,059.846$ & & \\
\hline Total & $3,683,925.518$ & 115 & & & & Total & $3,540,613.524$ & 115 & & & \\
\hline \multicolumn{6}{|c|}{ Coefficients } & \multicolumn{6}{|c|}{ Coefficients } \\
\hline & \multicolumn{2}{|c|}{ Unstandardized Coefficients } & \multicolumn{3}{|c|}{ Standard Coefficients } & & \multicolumn{2}{|c|}{ Unstandardized Coefficients } & \multicolumn{3}{|c|}{ Standard Coefficients } \\
\hline Model & B & $\begin{array}{c}\text { Std. } \\
\text { error }\end{array}$ & Beta & $\mathrm{T}$ & Sig & Model & B & Std. error & Beta & $\mathrm{T}$ & Sig \\
\hline Constant & 68.046 & 52.709 & & 1.291 & 0.199 & Constant & 122.365 & 45.317 & & 2.700 & 0.008 \\
\hline Structure & 63.022 & 36.572 & 0.160 & 1.723 & 0.088 & Structure & 61.422 & 35.211 & 0.159 & 1.744 & 0.084 \\
\hline ROA 1 & 276.988 & 125.881 & 0.203 & 2.200 & 0.030 & ROA 2 & 264.892 & 124.156 & 0.195 & 2.134 & 0.035 \\
\hline IO 1 & -132.570 & 76.243 & -0.165 & -1.739 & 0.085 & IO 2 & -119.756 & 70.799 & -0.157 & -1.692 & 0.094 \\
\hline CEO-Chairman Duality & -9.661 & 38.067 & -0.024 & -0.254 & 0.800 & CEO-Chairman Duality & -24.823 & 36.513 & -0.063 & -0.680 & 0.498 \\
\hline & $7.9 \%$ & & & & & 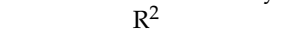 & $8.9 \%$ & & & & \\
\hline
\end{tabular}




\section{Conclusions}

In this paper, we examine the sample of Chinese firms cross-listed on U.S. exchanges in order to compare the market performance of dual-class vs single-class firms. We evaluate a sample of 121 Chinese firms cross-listed in U.S. exchanges which consist of 33 dual-class and 88 single-class firms. Our findings regarding market performance is contrary to the literature.

We find through descriptive analysis that dual-class firms underperform single-class firms in terms of operating performance measured by ROA and EPS prior to IPO, show improvement in the first year after IPO, and outperform in the second year after IPO. We also witness that dual-class firms outperform single-class firms in terms of market performance measured by $\mathrm{P} / \mathrm{E}$ ratio, Tobin's $\mathrm{Q}$, and abnormal stock return. This finding is contrary to the literature, the reasons of which are presented in the discussion of results part of our paper.

We then use OLS regression to compare market performance of single- vs dual class-firms of China measured by Tobin's $Q$, abnormal market return, and $\mathrm{P} / \mathrm{E}$ ratio. Interestingly, we find, contrary to the literature, that Chinese dual-class firms outperform single-class firms in terms of market performance. We find a significantly positive relationship between the structure choice of the firm and market performance variables used in this study for both years after IPO. We have to restrict our analysis to only two years as several dual-class firms were cross-listed in 2014. The possible reason for contrary results is that Chinese dual-class firms bond themselves to high standards from low local standards which show that insiders do not intend to destroy shareholder's value. Rather, they want to perform well in order to compete and survive in that market which imposes high standards.

There are several limitations of this study; the sample size of this study is quite small as we only have these Chinese firms cross-listed with U.S. exchanges yet. We cannot include Chinese firms cross listed to Singapore and Hong Kong because of reasons explained earlier in this paper. The duration of comparison also consists of only two years after IPO, which is very short, as we have to make the interval short as several dual-class firms cross-listed in 2014. Future researchers can compare Chinese dual-class firms with other developed country dual-class firms in order to determine the crux of this topic. Future researchers can also compare the performance of dual-class firms listed on U.S. exchanges with dual-class firms listed on other exchanges.

Acknowledgments: This research work is supported by National Natural Science Foundation of China (grant ID: 71371155).

Author Contributions: Abdullah generated idea of paper, collected data, performed experiments and wrote paper. Jia'nan Zhou refined the idea generated by Abdullah, designed experiments, helped in performing experiments, discussed results, reviewed paper several times and supervised at every step of paper. Muhammad Hashim Shah helped in brainstorming the idea, discussed and provided suggestions at every step of paper from brainstorming until the final acceptance of the paper, and also revised the paper.

Conflicts of Interest: The authors declare no conflicts of interest.

\section{References}

Abdullah, Jia'nan Zhou, and Muhammad Hashim Shah. 2017a. Dual-Class Firms: Evidence from IPOs of Chinese Firms Cross-Listed on U.S. Exchanges. Emerging Markets Finance and Trade 53: 1691-704. [CrossRef]

Abdullah, Jia'nan Zhou, and Muhammad Hashim Shah. 2017b. Effect of Structure Choice on Firm Governance: Evidence from Chinese Firms Cross Listed in U.S. Exchanges. Review of Integrative Business and Economics Research 6: 28-37.

Adams, Renée B., and João A. C. Santos. 2006. Identifying the effect of managerial control on firm performance. Journal of Accounting and Economics 41: 55-85. [CrossRef]

Amoako-Adu, Ben, and Brian F. Smith. 2001. Dual class firms: Capitalization, ownership structure and recapitalization back into single class. Journal of Banking E Finance 25: 1083-111.

Baulkaran, Vishaal. 2014. Management entrenchment and the valuation discount of dual class firms. The Quarterly Review of Economics and Finance 54: 70-81. [CrossRef] 
Bergström, Clas, and Kristian Rydqvist. 1990. Ownership of equity in dual-class firms. Journal of Banking E Finance 14: 255-69.

Bohmer, Ekkehart, Gary C. Sanger, and Sanjay B. Varshney. 1996. The effect of consolidated control on firm performance: The case of dual-class IPOs. In Empirical Issues in Raising Capital, Advances in Finance, Investment, and Banking. Amsterdam: Elsevier, pp. 95-124.

Chen, Xia, Jarrad Harford, and Kai Li. 2007. Monitoring: Which institutions matter? Journal of financial Economics 86: 279-305. [CrossRef]

Claessens, Stijn, Simeon Djankov, and Larry H. Lang. 2000. The separation of ownership and control in East Asian corporations. Journal of Financial Economics 58: 81-112. [CrossRef]

Claessens, Stijn, Simeon Djankov, Joseph P. Fan, and Larry H. Lang. 2002. Disentangling the incentive and entrenchment effects of large shareholdings. The Journal of Finance 57: 2741-771. [CrossRef]

Coffee, John C., Jr. 1998. Future as history: The prospects for global convergence in corporate governance and its implications. Northwestern University Law Review 93: 641. [CrossRef]

Coffee, John C., Jr. 2002. Racing towards the top?: The impact of cross-listings and stock market competition on international corporate governance. Columbia Law Review 102: 1757-831. [CrossRef]

Core, John E., Robert W. Holthausen, and David F. Larcker. 1999. Corporate governance, chief executive officer compensation, and firm performance. Journal of Financial Economics 51: 371-406. [CrossRef]

Cronqvist, Henrik, and Mattias Nilsson. 2003. Agency costs of controlling minority shareholders. Journal of Financial and Quantitative analysis 38: 695-719. [CrossRef]

Dey, Aiyesha, Valeri V. Nikolaev, and Xue Wang. 2016. Disproportional Control Rights and the Governance Role of Debt. Management Science 62: 2581-614. [CrossRef]

Doidge, Craig. 2004. U.S. cross-listings and the private benefits of control: Evidence from dual-class firms. Journal of Financial Economics 72: 519-53. [CrossRef]

Fosberg, Richard H., and Michale R. Nelson. 1999. Leadership structure and firm performance. International Review of Financial Analysis 8: 83-96. [CrossRef]

Giannetti, Mariassunta, and Andrel Simonov. 2006. Which Investors Fear Expropriation? Evidence from Investors' Portfolio Choices. The Journal of Finance 61: 1507-47. [CrossRef]

Gompers, Paul, Joy Ishii, and Andrew Metrick. 2003. Corporate governance and equity prices. The Quarterly Journal of Economics 118: 107-56. [CrossRef]

Gompers, Paul, Joy Ishii, and Andrew Metrick. 2010. Extreme Governance: An Analysis of Dual-Class Firms in the United States. Review of Financial Studies 23: 1051-88. [CrossRef]

Grossman, Sanford J., and Oliver D. Hart. 1988. One share-one vote and the market for corporate control. Journal of Financial Economics 20: 175-202. [CrossRef]

Hail, Luzi, and Christian Leuz. 2009. Cost of capital effects and changes in growth expectations around U.S. cross-listings. Journal of Financial Economics 93: 428-54. [CrossRef]

Jiang, Fuxiu, and Kenneth A. Kim. 2015. Corporate governance in China: A modern perspective. Journal of Corporate Finance 32: 190-216. [CrossRef]

Jog, Vijay, Peng-cheng Zhu, and Shantanu Dutta. 2010. Impact of restricted voting share structure on firm value and performance. Corporate Governance: An International Review 18: 415-37. [CrossRef]

Kajola, Sunday O. 2008. Corporate governance and firm performance: The case of Nigerian listed firms. European Journal of Economics, Finance and Administrative Sciences 14: 16-28.

Li, Kai, Hernan Ortiz-Molina, and Xinlei Zhao. 2008. Do Voting Rights Affect Institutional Investment Decisions? Evidence from Dual-Class Firms. Financial Management 37: 713-45. [CrossRef]

Lins, Karl V. 2003. Equity ownership and firm value in emerging markets. Journal of Financial and Quantitative Analysis 38: 159-84. [CrossRef]

Share. 2004. Second Class Investors. Vancouver, British Columbia: Shareholder Association for Research and Education, April, Vol. 505, pp. 1-33. Available online: http://www.share.ca/files/Second_Class_Investors. pdf (accessed on 1 May 2017).

Smart, Scott B., Ramabhadran S. Thirumalai, and Chad J. Zutter. 2008. What's in a vote? The short-and long-run impact of dual-class equity on IPO firm values. Journal of Accounting and Economics 45: 94-115. [CrossRef]

Smart, Scott B., and Chad J. Zutter. 2003. Control as a motivation for underpricing: A comparison of dual and single-class IPOs. Journal of Financial Economics 69: 85-110. [CrossRef] 
Stulz, Rene M. 1999. Golbalization, corporate finance, and the cost of capital. Journal of Applied Corporate Finance 12: 8-25. [CrossRef]

Tenev, Stoyan, Chunlin Zhang, and Loup Brefort. 2002. Corporate Governance and Enterprise Reform in China: Building the Institutions of Modern Markets. Washington: World Bank Publications.

Tian, Wen. 2013. You Can't Sell Your Firm and Own It Too: Disallowing Dual-Class Stock Companies from Listing on the Securities Exchange. University of Pennsylvania Law Review 162: 1495.

Yeh, Yin-Hua, and Tracie Woidtke. 2005. Commitment or entrenchment?: Controlling shareholders and board composition. Journal of Banking \& Finance 29: 1857-85.

Yermack, David. 1996. Higher market valuation of companies with a small board of directors. Journal of Financial Economics 40: 185-211. [CrossRef]

(C) 2017 by the authors. Licensee MDPI, Basel, Switzerland. This article is an open access article distributed under the terms and conditions of the Creative Commons Attribution (CC BY) license (http:/ / creativecommons.org/licenses/by/4.0/). 